\title{
CAUSES OF EARLY-AGE THERMAL CRACKING OF CONCRETE FOUNDATION SLABS AND THEIR REINFORCEMENT TO CONTROL THE CRACKING
}

\author{
Juraj BILČÍK ${ }^{1 *}$, Róbert SONNENSCHEIN², Natália GAŽOVIČOVÁ ${ }^{3}$
}

\section{Abstract}

This paper focuses on the causes and consequences of early-age cracking of mass concrete foundation slabs due to restrained volume changes. Considering the importance of water leaking through cracks in terms of the serviceability, durability and environmental impact of watertight concrete structures, emphasis is placed on the effect of temperature loads on foundation slabs. Foundation slabs are usually restrained to some degree externally or internally. To evaluate the effect of external restraints on foundation slabs, friction and interaction models are introduced. The reinforcement of concrete cannot prevent the initiation of cracking, but when cracking has occurred, it may act to reduce the spacing and width of cracks. According to EN 1992-1-1, results of calculating crack widths with local variations included in National Annexes (NAs) vary considerably. A comparison of the required reinforcement areas according to different NAs is presented.

\section{Address}

1, 2,3 Department of Concrete Structures and Bridges, Slovak University of Technology, Bratislava, Slovakia

* Corresponding author: juraj.bilcik@stuba.sk

Key words

- Watertight concrete

- Foundation slab,

- Restrained contractions,

- Early-age cracking,

- Reinforcement

\section{INTRODUCTION}

The main role of concrete in a construction is its structural function. Moreover, concrete can also have other functions, e.g., ensuring the watertightness or fire resistance of a structure. The watertightness of concrete in the past was mainly required for hydraulic structures. In recent years it has also expanded to include structures which undergo the effects of underground water, e.g., the substructures of buildings, underground garages and tunnels. Concrete structures such as underground basements normally have to be watertight to prevent damage due to moisture or the ingress of water. This can be achieved by applying an external waterproofing system either as a coating, a liner or another system applied to a surface or by using an integral watertight concrete structure (WCS) that renders the structural concrete watertight.

The stress which leads to cracking that arises in early-age (typically up to seven days) concrete is mainly associated with three types of changes in volume: autogenous shrinkage (induced by water absorption during the hydration of cement), drying shrinkage (induced by the evaporation of water while the concrete is curing), and thermal contraction (due to poor heat dissipation generated by the cement's hydration and cooling of hot concrete). Thermal stresses may induce early-age cracks (during construction) or structural damage and may further reduce the serviceability (e.g., watertightness) and durability of the structure. It has been shown that controlling the temperature is an effective way to prevent or reduce the risk of crack formation in concrete. Under slow cooling conditions, concrete can undergo a $20 \mathrm{~K}$ drop in temperature without cracking (Neville, 2011; Shi et al., 2014; Bobko et al., 2015). Early-age cracking occurs when the tensile strain that arises either from restrained thermal contractions or temperature differentials within a concrete section exceeds the actual tensile strain capacity of the concrete (Bamforth, 2007; Carino and Clifton, 1995; Mihashi and Leite, 2004). While such cracks do not typically impact structural integrity, they accelerate deterioration, reduce the serviceability of structures, and may be significant in environmental impact assessments by acting as paths of ingress for ions and/or moisture. The occurrence of thermal cracking is one of the clear limit states to be assessed in performance-based design (Maekawa et al., 1999). 
Although several strategies such as internal curing and the use of expansive cements or shrinkage-reducing admixtures have been developed to mitigate moisture-linked cracking, fewer options are available to mitigate thermal cracking (Fernandes et al., 2014; Sant, 2009). The ever-growing number of massive concrete structures impels a need to establish a strategy to reduce crack widths to values dictated by the autogenous healing process.

\section{WATERTIGHT CONCRETE CONSTRUCTION}

The basic dimensions and parameters (minimum thickness and maximum crack widths) of the structural elements of a WCS, i.e., the foundation slab and the wall, for various exposure and performance classes according to a German guideline (DAfStb, 2003) are shown in Table 1.

In terms of the formation and propagation of through cracks, there are three design models of the WCS according to DAfStb (DAfStb, 2003):
- without through cracks,

- with through cracks of a limited width - achieved by the design and detailing of reinforcement,

- with through cracks, without any crack control, and which are subsequently sealed.

Cracking is an inherent aspect of reinforced concrete and, if properly controlled, should not be detrimental to the performance of the structure (EN 1992-1-1, 2004; Kozikowski and Suprenant, 2015). The basis of the design of reinforced concrete is that concrete has no significant tensile strength and that sufficient reinforcement is provided to control crack widths. For the serviceability limit state of a WCS, the maximum crack width is between $0.05 \mathrm{~mm}$ and $0.2 \mathrm{~mm}$, depending on the ratio of the hydrostatic pressure to the thickness of the members (foundation slab and wall) (EN 1992-3). An increase in a crack width from 0.1 to $0.3 \mathrm{~mm}$ results in an increase in the penetrability of concrete by orders of magnitudes. With a crack width below $0.1 \mathrm{~mm}$, the penetrability is not much greater than that of the matrix, and these cracks can seal due to autogenous healing (Forth and Martin, 2014; Kovler and Bentur, 2009).

Tab. 1 The exposure and performance classes for a WCS (DAfStb, 2003)

\begin{tabular}{|c|c|c|}
\hline & Performance Class A & Performance Class B \\
\hline $\begin{array}{l}\text { Planned requirements exceeding } \\
\text { the extent of EN 1992-1-1 }\end{array}$ & $\begin{array}{l}\text { Any penetration of liquid water is strictly } \\
\text { prohibited (no humid spots, no water carrying } \\
\text { cracks and joints): } \\
\text { - Standard for dwelling buildings } \\
\text { - Storage space with high demands }\end{array}$ & $\begin{array}{l}\text { Water ingress permitted to a limited degree } \\
\text { (humid spots permitted, water carrying cracks } \\
\text { temporarily permitted until self-sealing): } \\
\text { - Underground garages } \\
\text { - Storage space with lower demands }\end{array}$ \\
\hline \multirow{4}{*}{$\begin{array}{l}\text { Exposure water Class } 1 \\
\text { Contact between structure and hydraulic } \\
\text { pressure: } \\
\text { - Ground, inundation and stratum water } \\
\text { under pressure, } \\
\text { - Temporary accumulation of leakage } \\
\text { water }\end{array}$} & $\begin{array}{l}\text { To display that occurrence of separation cracks } \\
\text { is not expected }\end{array}$ & \multirow{2}{*}{$\begin{array}{l}\text { Limiting width of separation cracks: } \\
\text { hydraulic slope: cracks width: } \\
\leq 10 \\
\begin{array}{ll}\text { from } 10 \text { to } 15 & 0.20 \mathrm{~mm} \\
\text { from } 15 \text { to } 25 & 0.15 \mathrm{~mm} \\
& 0.10 \mathrm{~mm}\end{array}\end{array}$} \\
\hline & $\begin{array}{l}\text { To display the min. thickness of compression } \\
\text { zone } x \geq 30 \mathrm{~mm} \text { and } x \geq 1.5 d_{\mathrm{g}} \\
\left(d_{\mathrm{g}} \text { max. aggregate size }\right)\end{array}$ & \\
\hline & $\begin{array}{l}\text { Wall thickness (monolithic and composite) } \\
\text { Foundation slab thickness }\end{array}$ & $\begin{array}{l}h \geq 240 \mathrm{~mm} \\
h \geq 250 \mathrm{~mm}\end{array}$ \\
\hline & When min. thickness than & $w / c \leq 0.55$, in walls $d_{\mathrm{g}} \leq 16 \mathrm{~mm}$ \\
\hline \multirow{3}{*}{$\begin{array}{l}\text { Exposure water Class } 2 \\
\text { Contact between structure and humidity or } \\
\text { water leaking through: } \\
\text { - Ground humidity } \\
\text { - Not accumulating leakage water }\end{array}$} & $\begin{array}{l}\text { Limiting crack width in wall } \\
\text { Limiting crack width in foundation slab }\end{array}$ & $\begin{array}{l}\leq 0.2 \mathrm{~mm} \\
\leq 0.3 \mathrm{~mm}\end{array}$ \\
\hline & $\begin{array}{l}\text { Wall txhickness monolithic (composite) } \\
\text { Foundation slab thickness }\end{array}$ & $\begin{array}{c}h \geq 200 \mathrm{~mm}(240 \mathrm{~mm}) \\
h \geq 150 \mathrm{~mm}\end{array}$ \\
\hline & Concrete water/cement ratio & $w / c \leq 0.60$ \\
\hline
\end{tabular}

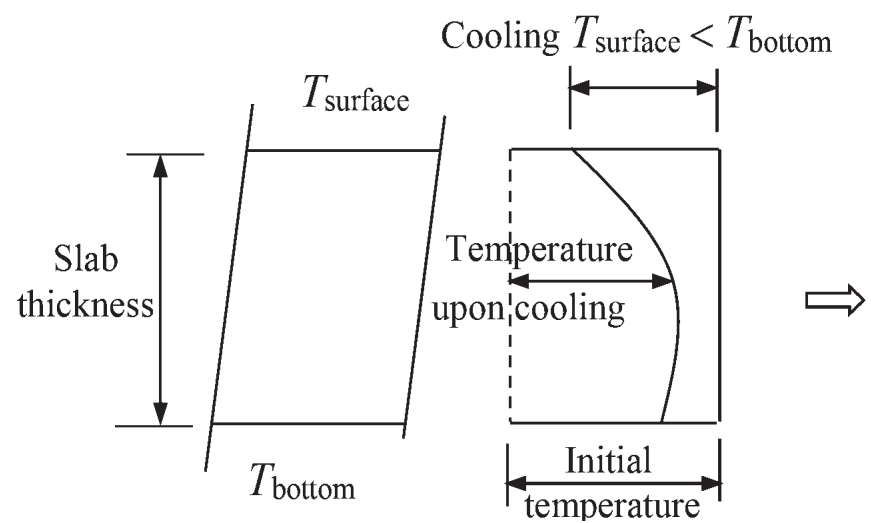

Imposed stresses Residual stress

Fig. 1 Analysis of the temperature and stress distribution across the height of a slab's cross section upon cooling (Springeschmid, 1984) 


\section{RESTRAINED IMPOSED DEFORMATION IN FOUNDATION SLABS}

Foundation slabs interact vertically and horizontally with the subsoil. Cracks can occur due to bending, shear, torsion or tension resulting from either direct loading or restrained imposed deformations. Changes in the volume of concrete foundation slabs would be of little consequence if the slabs were free of any restraint. Foundation slabs, however, are usually restrained to some degree by external (e.g., contact with the subgrade and edges) or internal restraints (e.g., reinforcement, differences in temperature); as a result, significant tensile stresses can develop.

While concrete is hardening, differences in temperature between the core and the surfaces of the slab are produced as a result of internal restraints (different thermal boundary conditions). At the same time, constant, linear and nonlinear (residual) distributed stresses rise in the cross-section. The distribution of the associated stress components in the cross section of a foundation slab is shown in Fig. 1.

There are two types of model for evaluating the effect of external restraints in foundation slabs. The friction model (Fig. 2a) assumes slippage over a rigid bedding area and is mainly applicable to thin or short slabs. With the increasing length or thickness of a slab, the slippage becomes less important as the area with a full bond between the slab and the subsoil increases. In this case, with the second type, i.e., the interaction model, the relationship between the foundation slab and the subsoil, or rather the elasticity of the subsoil, is the focus, as illustrated in Fig. 2b (Schlicke and Tue, 2015).

There are no general requirements concerning the deformability of the subsoil under the slab. All standard constructions and all simple design methods presume a well-compacted subsoil with a high modulus of deformation, i.e., quasi-infinite stiffness (RILEM, 2006).

\subsection{The friction model}

To minimize tensile stresses in foundation slabs, interlinkages with the subsoil should be avoided, and the sliding friction between the concrete slab and the subsoil should be reduced to a minimum. In the case of skidding friction, the normal force $N$ in the foundation slab responsible for the formation of early-age cracks is as follows:

(a)

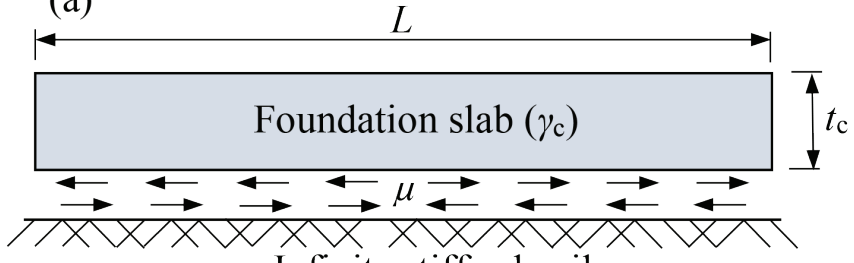

(b)

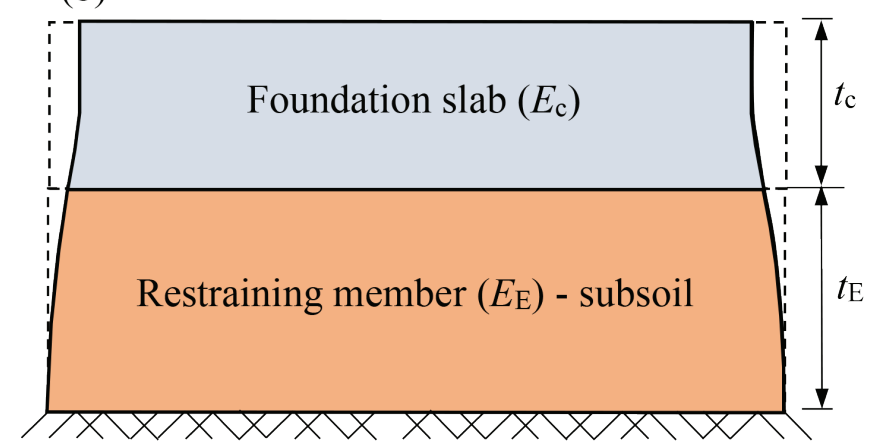

Fig. 2 The models used when considering the external restraint of foundation slabs due to friction and horizontal interaction with the subsoil: (a) friction model; (b) interaction model (Schlicke and Tue, 2015) where:

$$
N=1 / 2 \cdot \mu \cdot l \cdot b \cdot t \cdot \gamma_{c}
$$

$\mu \quad$ is the friction coefficient between the foundation slab and subsoil,

$l, b, t$ are the length, width and thickness of the foundation slab, respectively,

$\gamma_{c} \quad$ is the weight density of the concrete.

As shown in the equation, the tensile stress depends on the friction coefficient and the length of the foundation slab. Therefore, only two actions can realistically be taken in order to reduce the stress:

- the arrangement of sliding foils between the foundation slab and subsoil,

- the layout of the construction joints.

The reduction of the sliding friction through suitable sliding layers (e.g., a double layer of PE foil on a smooth blinding layer) involves a relatively low amount of effort/cost, but especially with thick foundation slabs, it is only partly successful. However, with thinner slabs and high-quality sliding layers (PTFE-coated foil, welded bitumen sheets), considerable improvement can be achieved (Becker, 2009; Čajka et al., 2006).

\subsection{The interaction model}

The effect of a slab's thickness and the external restraint on stresses caused by the hydration of concrete was calculated with a 3D-FEM model (Schlicke and Tue., 2015). Even if the scope of the resulting stresses is restricted to certain conditions (concrete C35/45, CEM III/A32.5 N, concreting in the summer), the results are suitable for a general understanding of this issue.

Considering the horizontal yielding of the subsoil and the deformation compatibility, the upper limit of the restraint force $N_{\max }$ can be derived as follows:

$$
N_{\max }=-\varepsilon_{0} \cdot E_{\mathrm{c}} A_{\mathrm{c}} \cdot \frac{1}{1+\frac{E_{\mathrm{c}} A_{\mathrm{c}}}{E_{\mathrm{E}} A_{\mathrm{E}}}}
$$

where:

$\varepsilon_{0} \quad$ is the deformation impact,

$E_{\mathrm{c}}, A_{\mathrm{c}}$ are the modulus of elasticity of the concrete and the area of the concrete, respectively,

$E_{\mathrm{E}}, A_{\mathrm{E}}$ are the horizontal modulus of elasticity of the subsoil and the activated area of the subsoil, respectively.

The general case involves the risk of bending cracks on the top surface, which are more or less independent of the subsoil's stiffness. The formation of through cracks requires high external restraint. Therefore, where high external restraint conditions exist, the effects of internal restraint may be negligible (ACI 207.2R-07, 2007).

Based on the model results (Schlicke et al., 2015), the following general statements on the risk of cracks and the type of cracks in foundation slabs can be made:

- the risk of micro-cracks on the top surface increases with the slab's thickness,

- bending restraint on the top surface is relevant in the design of slabs with large horizontal dimensions since it is more likely that the crack moment will be reached,

- in general, there is a low risk of the formation of through cracks over the height of the slab,

- the through cracks propagate from the bottom surface.

On the other hand, a review (Bamforth, 2007) of the development of the approaches in both BS 8007 and EN1992-1-1 has led to the conclusion that the underlying assumption that cracking is prop- 


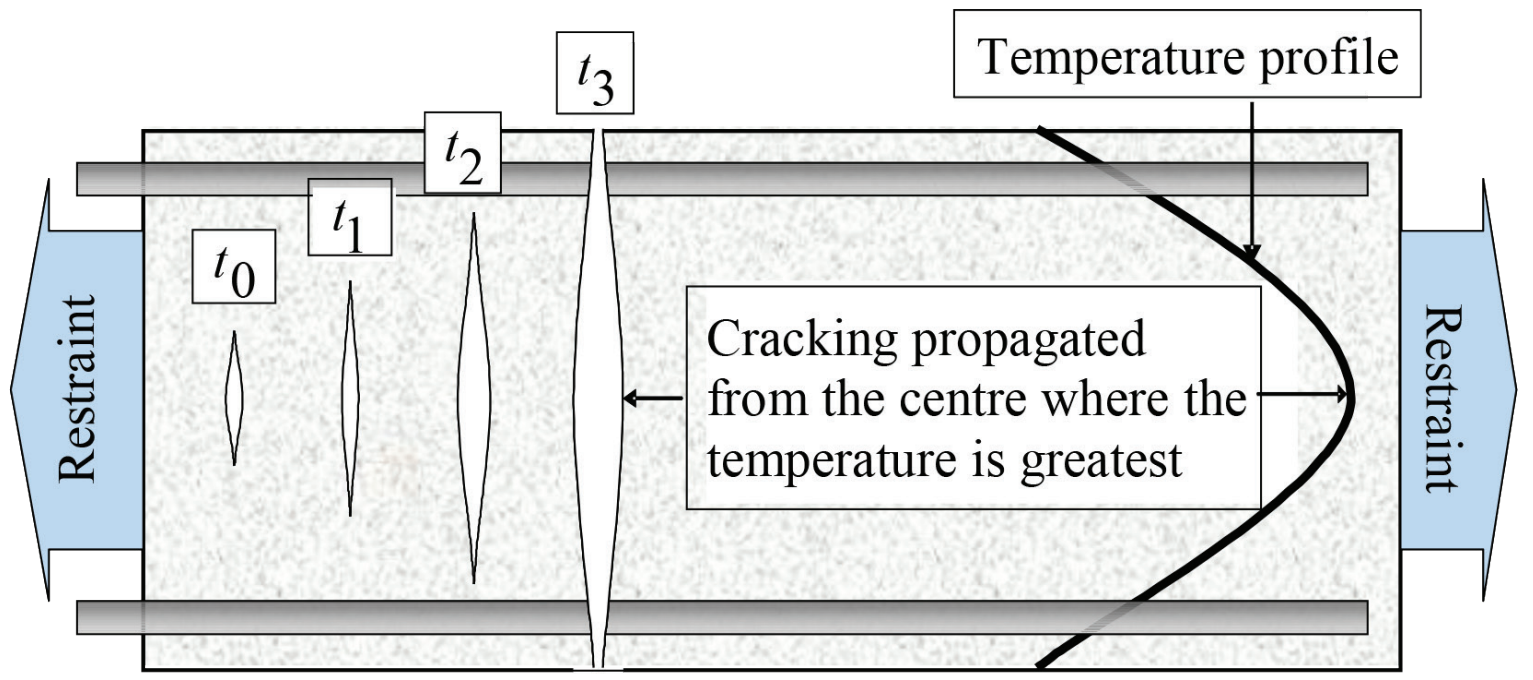

Fig. 3 Development of cracking in a thick, externally restrained, section during cooling (Bamforth, 2007)

agated from the surface does not apply to thick sections subjected to external restraint. Under these conditions cracking is more likely to propagate from the centre where the rise and fall in temperature are greatest, as illustrated in Fig. 3.

\section{DESIGN OF REINFORCEMENT TO CONTROL CRACKING}

Steel reinforcement is provided to carry the tensile stresses caused by direct loading or restraints on contraction. The use of reinforcement will not prevent cracking, but will actually increase the frequency of cracks while reducing their width. The design of a reinforcement to control cracking is based on the methods of EN 19921-1 and EN 1992-3. It is normal practice to design the reinforcement to meet the requirements for structural loading and then to check that the reinforcement area is adequate both to control early-age cracking and to limit the width of cracks.

EN 1992 require a minimum area of reinforcement calculated on the basis of a requirement to achieve steel stresses below the yield strength of the steel. Based on expression 7.1 of EN 1992-1-1, $A_{\mathrm{s}, \mathrm{min}}$ may be calculated using the expression

$$
A_{\mathrm{s}, \min }=k_{\mathrm{c}} k A_{\mathrm{ct}}\left(f_{\mathrm{ct}, \mathrm{eff}} / f_{\mathrm{yk}}\right)
$$

where:

$k_{\mathrm{c}} k A_{\mathrm{ct}}$ is the effective area of the concrete in tension,

$f_{\text {ct,eff }}$ is the effective tensile strength of the concrete at the time of cracking,

$f_{\mathrm{yk}} \quad$ is the characteristic yield strength of the reinforcement.

If a minimum area of steel consistent with $A_{\mathrm{s} \text { min }}$ is used, the stress in the steel after cracking would be expected to be close to the yield stress, $f_{\mathrm{yk}}=500 \mathrm{MPa}$. It is not normal practice to design the reinforcement to operate at this high level of stress, as this would lead to wide cracks. In watertight structures, it is expected that the provided area of steel $A_{\mathrm{s}}$ should be significantly higher than $A_{\mathrm{s}, \mathrm{min}}$.

Both the calculations and experiments show that reinforcement can postpone the occurrence of the appearance of the first major crack and can enhance the ultimate tensile strain of the structure (Shi et al., 2014; Sule, 2003). In terms of temperature strains, this would mean that an additional temperature difference of up to $10.8 \mathrm{~K}$ could be accommodated (Sule and van Breugel, 2004).

Tab. 2 Nationally determined parameters of EN 1992-1-1

\begin{tabular}{|c|c|c|c|c|c|}
\hline Parameters & $\begin{array}{c}\text { Original } \\
\text { EN 1992-1-1 }\end{array}$ & $\begin{array}{c}\text { German National } \\
\text { Annex }\end{array}$ & $\begin{array}{c}\text { Czech National Annex } \\
\text { (Šmejkal and Procházka, 2015) }\end{array}$ & $\begin{array}{c}\text { Austrian National } \\
\text { Annex }\end{array}$ & $\begin{array}{c}\text { prEN } \\
1992-1-1(2017-04)\end{array}$ \\
\hline$k_{1}$ & $\begin{array}{l}0.8 \\
1.6\end{array}$ & 1.0 & $\begin{array}{l}0.8 \\
1.6\end{array}$ & $\begin{array}{l}0.8 \\
1.6\end{array}$ & $\begin{array}{l}0.8 \\
1.6\end{array}$ \\
\hline$k_{2}$ & $\begin{array}{l}0.5 \\
1.0\end{array}$ & 1.0 & $\begin{array}{l}0.5 \\
1.0\end{array}$ & $\begin{array}{l}0.5 \\
1.0\end{array}$ & 1.0 \\
\hline$k_{3}$ & 3.4 & 0 & $3.4^{*}(25 / c)^{2 / 3}$ & 0 & 2.0 \\
\hline$k_{4}$ & 0.425 & $1 / 3.6$ & 0.425 & $1 / 3.6$ & 0.35 \\
\hline$h_{\mathrm{c}, \mathrm{ef}}$ & $2.5 * d_{1}$ & $(2.5 \div 5.0) * d_{1}$ & $2.5 * d_{1}$ & $(2.5 \div 5.0) * d_{1}$ & $2.5 * d_{1}$ \\
\hline $\begin{array}{l}h \leq 0.3 \mathrm{~m} \\
h \geq 0.8 \mathrm{~m}\end{array}$ & $\begin{array}{c}1.0 \\
0.65\end{array}$ & $\begin{array}{l}0.8 \\
0.5\end{array}$ & $\begin{array}{c}1.0 \\
0.65\end{array}$ & $\begin{array}{l}0.8 \\
0.5\end{array}$ & $\begin{array}{l}1.0 \\
0.65\end{array}$ \\
\hline$f_{\text {ct,eff }}$ & $f_{\mathrm{ctm}}(t)$ & $\begin{array}{l}0.5 * f_{\mathrm{ctm}} \\
1.5 \mathrm{MPa}\end{array}$ & $0.5^{*} f_{\mathrm{ctm}}$ & $\begin{array}{l}0.5 * f_{\mathrm{ctm}} \\
1.5 \mathrm{MPa}\end{array}$ & $f_{\mathrm{ctm}}(t)$ \\
\hline
\end{tabular}




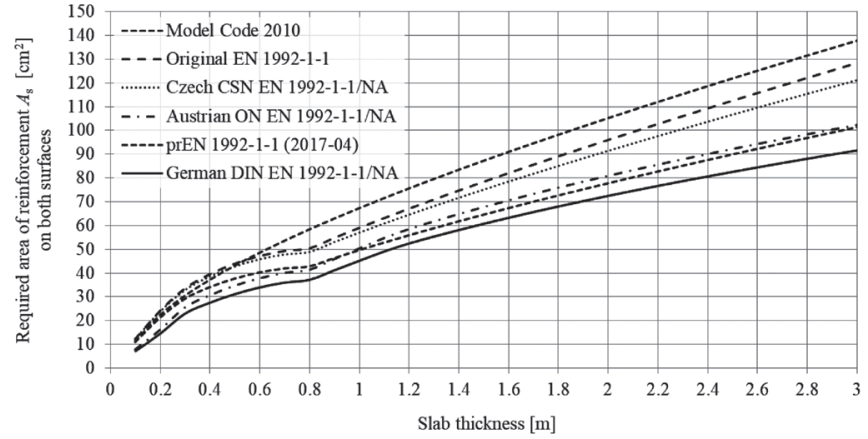

Fig. 4 Comparison of the required reinforcement area according to the NDP in NA of EN 1992-1-1 and Model Code 2010 (Sonnenschein et al., 2016)

\subsection{Control of crack widths according to EN 1992-1-1}

The results from calculating crack widths can vary considerably when using the Nationally Determined Parameters (NDP) in the National Annexes (NAs) of EN 1992-1-1 (see Table 2). The Slovak National Annex is identical with the original version of EN 1992-1-1 in section 7.3 "Crack control".

A comparison of the reinforcement areas in Fig. 4 was made under the NDP in Table 2 and Model Code 2010 (fib 2012). The comparison was based on the following parameters:

- concrete class $\mathrm{C} 25 / 30$ and cement class N,

- reinforcing bars grade B 500B with a diameter of $16 \mathrm{~mm}$,

- structural class $\mathrm{S} 3$, exposure class $\mathrm{XC} 2, \mathrm{XC} 3 \Rightarrow$ the cover to the longitudinal reinforcement is $30 \mathrm{~mm}$,

- maximum crack width $w_{\mathrm{k}, \max }=0.2 \mathrm{~mm}$

- age of the concrete $t=5$ days.

To interpret the presented results, it must be considered that according to the German DIN EN 1992-1-1/NA and Austrian ÖN 1992$1-1$, the crack width is calculated at the level of the reinforcement bar, while according to other national standards, it is calculated on the concrete surface. For most practical purposes it is sufficient to measure the crack width on the surface. At the reinforcement level, the crack width measured is almost independent of the concrete cover. The difference between the crack width at the steel level and the surface at a stress of $\sigma_{\mathrm{s}}=250 \mathrm{MPa}$ is approximately $\Delta w \approx 0.1 \mathrm{~mm}$ on average. This deviation increases with increases in the steel stress and the thickness of the concrete cover (Empelmann and Krakowski, 2015). Calculating crack width at the level of the steel bar allows for savings of around $20 \%$ of the reinforcement. On the other hand, this increases the risk of exceeding the limiting crack width for autogenous healing.

\subsection{Control of cracks in concrete according to different strength classes}

An increase in a concrete strength class has an adverse effect on the required reinforcement area. The minimum reinforcement to control cracks due to imposed deformations on restrained foundation slabs is calculated such that the reinforcement is able to transfer the tension without yielding. It follows, therefore, that the stronger the concrete, the greater the amount of reinforcement that will be required to achieve controlled cracking. The tensile strength of concrete at the time when the first cracking might be expected is the effective tensile strength $f_{\text {ct,eff }}$ that should be used (MPA 2015). It is important, therefore, that an appropriate value of $f_{\text {cteff }}$ is adopted in the design

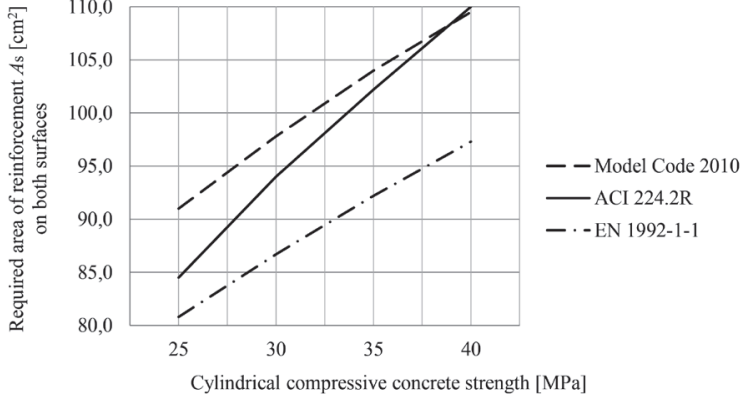

Fig. 5 Required reinforcement area in a foundation slab for different compressive strengths of concrete

process. Using too high a value will lead to an unnecessarily high volume of reinforcement, while assuming too low a value leads to the risk of the cracks exceeding the allowable width. Often, for early age cracking $f_{\text {ct eff }}=0.5 f_{\text {ctm }}$ is considered critical.

A comparison of the required area of steel $A_{\mathrm{s}}$ for controlled cracking for different compressive strengths of concrete cylinders according to EN 1992-1-1 (CEN 2004), Model Code 2010 (fib 2012), and ACI 224.2R-92 (ACI 2004) is shown in Fig. 5. The calculations were performed for early-age cracking (five days after casting) and indicated a maximum crack width of $0.2 \mathrm{~mm}$ for a foundation slab with bars with a diameter of $25 \mathrm{~mm}$, cement class $\mathrm{N}$-normal hardening, a concrete cover of $30 \mathrm{~mm}$, and the thickness of the foundation slab $1.0 \mathrm{~m}$.

Creep provides increased resistance to crack formation in a foundation slab. Thus, lower strength concretes which experience more creep than higher strength concretes provide additional cracking resistance.

\section{CONCLUSIONS}

This paper presents an overview of the effects of thermal cracking on concrete foundation slabs. Mass concrete structures have a much higher risk of significant thermal cracking. Early-age cracks due to restrained thermal contractions can be serious because, unlike flexural cracks, they can extend through the full depth of the member. The crack width limitation is an important step to ensure the serviceability and durability of massive concrete members. More care should be taken in controlling the temperatures and reinforcement in such massive concrete structures.

Based on the results presented, the following conclusions could be made:

1. Temperature changes are the main reason for the formation of early-age through cracks in massive foundation slabs. This cracking is more likely to propagate from the middle of the cross section where the rise and fall in the temperature are greatest.

2. In general, when assessing the risk of early-age cracking, drying and autogenous shrinkage may be ignored.

3. The quantity of reinforcement designed using Eq. 3 is not enough to prevent the leakage of water due to cracks in watertight concrete structures.

4. A comparative study revealed differences in the required reinforcement area and differences in the level of the crack widths measured:

- the results of calculating crack widths can vary considerably when using the Nationally Determined Parameters in the Na- 
tional Annexes of EN 1992-1-1,

- crack widths are calculated on the concrete surface or at the level of the reinforcement bar. The latter allows for savings of around $20 \%$ on any reinforcement.

5. When-higher strength concrete is used, the amount of reinforcement that will be required to limit the specified crack widths needs to be increased. The calculations according to ACI 224.2R-92 (ACI 2004) are more sensitive to an increase in the concrete's strength than the corresponding CEN and fib standards.

\section{Acknowledgements}

This work was supported by VEGA research project No. 1/0583/15 "Analysis of the Reliability Risks in the Design and Execution of Concrete Structures" and the University Science Park of the Slovak University of Technology in Bratislava (ITMS: 26240220084).

\section{REFERENCES}

ACI 207.2R-07 (2007) Report on Thermal and Volume Change Effects on Cracking of Mass Concrete. ACI Committee 207, 28 pp.

ACI 224.2R-92 (ACI 2004) Cracking of Concrete Members in Direct Tension. ACI Committee 224, 12 pp.

Bamforth, P.B. (2007) Early-age thermal crack control in concrete. CIRIA C660, London, 112 pp.

Becker, A. (2009) Waterproof Concrete Tanks. Tiefbau 3, pp. 153161

Bobko, C.P. - Edwards, A.J., Seracino, R. and Zia, P. (2015) Thermal Cracking of Mass Concrete Bridge Footings in Coastal Environments. Journal of Performance of Constructed Facilities, Vol. 29, No. 6, pp. 1-11

British Standard (BS) 8007. (1987) Design of Concrete Structures for Retaining Aqueous Liquids. British Standards Institution, 32 pp.

Čajka, R. - Maňásek, P. - Sekanina, D. (2006) Reduction of Volume Changes of Concrete - Effects on State of Stress of Foundation. Proceedings of the International RILEM Conference on Volume Changes in Hardening Concrete, Lyngby, Denmark, pp. 195-204

Carino, N.J. - Clifton, J.R. (1995) Prediction of Cracking in Reinforced Concrete Structures. NISTIR Report No.5634, 51 pp.

Deutscher Ausschuss für Stahlbeton (DAfStb) (2003) Richtlinie Wasserunduchlässige Bauwerke aus Beton (WU-Richtlinie) (Guideline Watertight Concrete Structures (WCS-Guideline)). 18 pp. (in German)

Empelmann, M. - Krakowski, W. (2015) Erweitertes Modell zur Berechnung der Rissbreite (Extended model to calculate the crack width). Beton- und Stahlbetonbau, Vol. 110, No. 7, pp. 458 -467 (in German)

EN 1992-1-1. (2004) Design of Concrete Structures - Part 1-1: General Rules and Rules for Buildings. 225 pp.

EN 1992-3. (2006) Design of Concrete Structures - Part 3: Liquid Retaining and Containment Structures. 23 pp.

Fernandes, F. et al. (2014) On the feasibility of using phase change materials (PCMs) to mitigate thermal cracking in cementitious materials. Cement \& Concrete Composites, 51, pp. 14-26

Forth, J.P. - Martin, A.J. (2014) Design of Liquid Retaining Concrete Structures. Whittles Publishing, 192 pp.
Kovler, K. - Bentur, A. (2009) Cracking Sensitivity of Normal- and High-Strength Concretes. ACI Materials Journal, Vol. 106, No. 6, pp. 537-542

Kozikowski, R.L. - Suprenant, B.A. (2015) Controlling Early-Age Cracking in Mass Concrete. Concrete International, Vol. 37, No. 3 , pp. $59-62$

Maekawa, K., - Chaube, R. - Kishi, T. (1999) Modelling of Concrete Performance: Hydration Microstructure Formation and Mass Transport. Taylor \& Francis, 312 pp.

Mihashi, H. - de B. Leite, J.P. (2004) State-of-the-Art Report on Control of Cracking in Early Age Concrete. Journal of Advanced Concrete Technology, No. 2, Vol. 2, pp. 141-154

Mineral Products Association - MPA (2015) Concrete Design Guide. No. 1: Guidance on the design of liquid-retaining structures. The Structural Engineer, Jan. 2015, pp. 44-48

Model Code 2010. (2013) fib Model Code for Concrete Structures 2010. 434 pp.

Neville, A.M. (2011). Properties of Concrete. $5^{\text {th }}$ edition, Pearson Education Limited, $2865 \mathrm{pp}$.

prEN 1992-1-1. (2017-04) Design of Concrete Structures - Part 1-1: General Rules and Rules for Buildings. 261 pp.

RILEM TC 184-IFE. (2006) 'Industrial Floors'. State-of-the-art Report. Report No. 33, 141 pp.

Sant, G.N. (2009) Fundamental investigations related to the mitigation of volume changes in cement-based materials at early ages. PhD Dissertation, Purdue University, 201 pp.

Schlicke, D. - Tue, N.V. (2015) Minimum reinforcement for crack width control in restrained concrete members considering the deformation compatibility. Structural Concrete, No. 2, pp. 221-232

Shi, N. - Ouyang, J. - Zhang, R. - Huang, D. (2014) Experimental Study on Early-Age Crack of Mass Concrete under the Controlled Temperature History. Advances in Materials Science and Engineering, Hindawi Publishing Corporation, 10 pp.

Šmejkal, J. - Procházka, J. (2015) Výpočet šǐrky trhlin - 2. část (Calculation of Crack Widths $-2^{\text {nd }}$ part). BETON TKS, Vol. 17, No. 1, pp. $72-78$ (in Czech)

Sonnenschein, R. - Bilč́k, J. - Gajdošová, K. (2016) Parameter Analysis of the Reinforcement for the Width and Spacing Control 
of the Early-Age Cracks in Concrete. Key Engineering Materials, Trans Tech Publication, Vol. 691, pp. 14-27

Springeschmid, R. (1984) Die Ermittlung von Spannungen infolge von Schwinden und Hydratationswärme in Beton (Determining stresses due to the shrinkage and heat from hydration in concrete). Beton- und Stahlbetonbau, No. 10, pp. 263-269 (in German)
Sule, M.S. (2003) Effect of Reinforcement on Early-Age Cracking in High Strength Concrete. Master's Thesis, TU Delft, 154 pp.

Sule, M. - van Breugel, K. (2004) The effect of reinforcement on early-age cracking due to autogenous shrinkage and thermal effects. Cement \& Concrete Composites, Vol. 26, No. 5, pp. 581-587 